\title{
HUBUNGAN ANTARA INDEKS PRESTASI DENGAN PENAMPILAN KERJA PERAWAT LULUSAN AKPER PAMENANG PARE DI RSUD. PARE KEDIRI
}

\author{
Christianto Nugroho \\ Bidang Keperawatan, Akademi Keperawatan Pamenang Pare - Kediri
}

\begin{abstract}
The nurse job performance influenced by many factors, one of them is prestation indeks. Prestation Indeks consit of general lecture, nursing basic lecture, and profesion lecture indeks. These are indicated their ability about nursing science. But Nurse performance has not evaluated well. This research was aimed to investigate the influence prestation indeks to nurse job performance in Pare hospital.

Design used in this research was cross sectional study. The samples are nurses in Pare Hospital, who graduated from Akper Pamenang. These are 44 respondens, selected with total sampling. The data collected by quisioner and observation then analyzed with SPSS Linier Regretion with Significan level $p<0,05$.

Results showed that general lecture prestation indeks had corelation with nurse job performance $(p=0,005)$, profession basic lecture prestation indeks had corelation with nurse job performance $(p=0.004)$, profession lecture indeks had corelation with nurse job performance $(p=0,003)$ and comulatif prestation indeks had corelation with nurse job performance $(p=0,014)$.

It can be concluded that indeks influenced nurse job performance especially general lecture, profesion basic lecture and profession lecture prestation indeks. So it will recomended to choose higher prestation indeks in nurse recruitment.
\end{abstract}

Keywords : Prestation indeks-Nurse- job performance

\section{PENDAHULUAN}

Pendidikan keperawatan sebagai institusi yang mengembangakan dan menciptakan tenaga keperawatan memiliki peran yang sangat besar dalam profesionalisasi keperawatan, pendidikan keperawatan mampu memberikan bentuk dan corak tenaga keperawatan dari lulusannya ( Ma'rifin, 1999). Akper Pamenang Pare, salah satu institusi pendidikan yang meneyelenggarakan Program DIII Keperawatan berdiri pada tahun sesuai SK DIKTI No. 194 / D / O / 2003, telah meluluskan 100 tenaga perawat.

Selama 2 tahun ini telah dilakukan evaluasi terhadap indeks prestasi lulusan Akper Pamenang Pare. Hasil dari evaluasi tersebut, sebagian besar berpredikat sangat memuaskan pada IPK dan IP MKU, dan sebagian besar memuaskan pada IP MKDK dan IP MKK. Namun selama ini belum pernah dilakukan evaluasi yang terstruktur dan sistematis terhadap penampilan kerja lulusan Akper Pamenang Pare. Sehingga belum ada acuan untuk penetapan kurikulum institusi yang sesuai dengan kebutuhan masyarakat, akibat belum jelasnya kelompok mata kuliah mana yang lebih relevan terhadap penampilan kerja lulusan.
Dalam Laporan Pendidikan yang disampaikan Direktur pada wisuda II tahun 2007, Akper Pamenang Pare telah meluluskan 100 alumni: 100 dari program umum. Dari sejumlah lulusan selama 2 tahun terakhir, yang lulus dengan IPK berpredikat dengan pujian $26 \%$, sangat memuaskan $64 \%$, dan memuaskan $10 \%$. Prediakt pada IP MKU dengan pujian 30\%, sangat memuaskan $60 \%$, memuaskan $10 \%$. Predikat pada IP MKDK 25\% dengan pujian, sangat memuaskan 70\%, memuaskan 5\%. Predikat pada IP MKK 20\% dengan pujian, 56\% sangat memuaskan dan $24 \%$ memuaskan (BAAK, 2007). Sedangkan menurut hasil pengumpulan data tahun 2007 sekitar $60 \%$ lulusan dimagangkan di RSUD Pare Kediri. Walaupun belum ada penelitian penampilan kerja lulusan Akper Pamenang Pare, namun ditemukan keluhan beberapa perawat senior tentang penampilan kerja lulusan yang kurang bagus.

Sampai saat ini belum ada data yang sistematis tentang penampilan kerja lulusan Akper Pamenang Pare. Bila hal ini berlanjut kurikulum instituisi yang ditetapkan tidak dapat memberi jaminan kepada masyarakat sehingga menghasilkan lulusan yang tidak mampu mengatasi masalah kesehatan masyarakat pada masa kini dan mendatang 
Oleh karena itu perawat diharapkan dapat mendefinisikan, mengimplementasikan, dan mengukur perbedaan bahwa praktik keperawatan harus dapat sebagai indikator terpenuhinya kebutuhan masyarakat akan pelayanan kesehatan yang profesional dimasa depan. Sesuai dengan hakekatnya sebagai pendidikan profesi, maka kurikulum pendidikan tinggi keperawatan disusun berdasarkan lingkup konsep pendidikan yang kokoh mencakup : penguasaan IPTEK keperawatan, menyelesaikan masalah secara ilmiah, sikap, tingkah laku dan kemampuan profesional, belajar sendiri dan mandiri, serta belajar dimasyarakat (Nursalam, 2002). Sebagai langkah awal untuk melaksanakan hal tersebut diatas maka perlu dilakukan evaluasi terhadap penampilan kerja perawat lulusan Akper Pamenang Pare.

\section{METODE PENELITIAN}

Penelitian ini dengan menggunakan metode kualitatif sebagai metode utama dan didukung oleh metode kuantitatif. Desain penelitian yang digunakan dalam membuat suatu "hubungan antara indeks prestasi dengan prestasi kerja lulusan Akper Pamenang Pare" yaitu cross sectional dimana menghubungkan antara dua variabel di dalam penelitian yaitu indeks prestasi dan prestasi kerja.

Insrumen yang digunakan dalam penelitian ini adalah instrumen observasi untuk menilai : (1) Indeks Prestasi Kumulatif, (2) Indeks Prestasi MKU, (3) Indeks Prestasi MKDK, Indeks Prestasi MKK, sedangkan penilaian Penampilan Kerja perawat dilakukan dengan observasi yang dilakukan oleh kepala bagian ruang RSUD. Pare meliputi 4 kriteria yaitu : (1) Keterampilan Asuhan Keperawatan (2) Perilaku Bekerja (3) Cara Berpikir dan (4) Perilaku Sosial.

Data yang telah diedit disajikan secara tabulasi antara variabel independen dan variabel dependen, selanjutnya dianalisa dengan menggunakan tehnik analisa Regresi linier berganda. Persamaan regresi berganda untuk empat prediktor yaitu :

$$
Y=a+b 1 \times 1+b 2 \times 2+b 3 \times 3+b 4 \times 4
$$

maka hubungan antar variabelnya secara lengakap dinyatakan sebagai berikut:

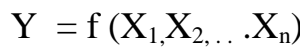

Uji ini digunakan untuk mengetahui derajat atau kekuatan hubungan antara variabel indeks prestasi komulatif $\left(\mathrm{X}_{1}, \mathrm{X}_{2, \ldots}\right)$ secara serempak atau bersamasama dengan variabel penampilan kerja pasien (Y), maka digunakan koefesien korelasi berganda. Korelasi ini dapat diperoleh dengan mengambil akar dari koefisien determinasi ( $\mathrm{R}$ ). Untuk mengetahui apakah $\mathrm{R}$ yang diperoleh signifikan (bermakna) atau tidak tidak signifikan, maka dipakai uji $\mathrm{F}$ $\mathrm{R}^{2}(\mathrm{~N}-\mathrm{m}-1)$

$\mathrm{m}\left(1-\mathrm{R}^{2}\right)$

$$
\mathrm{F}=\ldots \ldots \ldots \ldots
$$

Hasil uji F nantinya akan diperoleh :

a) Pengujian dilakukan dengan menggunakan uji $\mathrm{F}$ dua arah, dengan derajat kebebasan : df $=(\mathrm{k})$. $(\mathrm{n}-\mathrm{k}-$ 1)

b) Dengan daftar kepercayaan $\alpha=0,05$

c) Merumuskan hipotesis sebagai berikut:

Jika $\mathrm{F}$ hitung $>\mathrm{F}$ tabel, maka Ho ditolak dan $\mathrm{Ha}$ diterima, berarti diperoleh signifikan. Dengan demikian tidak diragukan lagi bahwa variabel $\mathrm{X}_{1} \mathrm{X}_{2, \ldots \ldots \ldots}$ secara bersama- sama berhubungan terhadap variable $\mathrm{Y}$.

Jika $\mathrm{F}$ hitung < F tabel, maka Ho diterima dan $\mathrm{Ha}$ ditolak, berarti korelasi diperoleh tidak signifikan. Dengan demikian tidak diragukan lagi bahwa variabel $\mathrm{X}_{1}, \mathrm{X}_{2, \ldots \ldots \ldots \ldots . . .}$ secara bersama- sama tidak berhubungan terhadap variabel $\mathrm{Y}$.

\section{HASIL PENELITIAN}

Hubungan Indeks Prestasi MKU, MKDK, MKK, dan Komulatif dengan penampilan Kerja Lulusan Akper Pamenang di RSUD Pare.

\begin{tabular}{|c|c|c|}
\hline Hubungan & \multicolumn{2}{|c|}{$\begin{array}{c}\text { Nilai Analisis Regresi } \\
\text { IP dengan }\end{array}$} \\
\cline { 2 - 3 } $\begin{array}{c}\text { Penampilan } \\
\text { Kerja }\end{array}$ & $\begin{array}{c}\text { Koefisient } \\
\text { Korelasi }(r)\end{array}$ & $\begin{array}{c}\text { Signifikansi } \\
(p)\end{array}$ \\
\hline MKU & 0,382 & 0,005 \\
\hline MKDK & 0,394 & 0,004 \\
\hline MKK & 0,412 & 0,003 \\
\hline IPK & 0,330 & 0,014 \\
\hline
\end{tabular}

\section{PEMBAHASAN}

IP MKU ini meliputi prestasi pada kelompok Mata Kuliah Umum yaitu Kelompok Ilmu Humaniora, Alam Dasar, Ilmu Perilaku dan Ilmu Sosial. Pada Kenyataanya lulusan angkatan I,II,III yang bekerja di RSUD Pare kebanyakn mereka yang 
memilki jurusan diluar IPA sehingga akan berpengaruh pada rendahnya pemahaman mereka tentang konsep ilmiah Biologi dan Fisika yang sebenarnya sangat dibutuhkan dalam membentuk pola pikir ilimiah dalam pelayanan keperawatan. Hal ini memungkinkan sebagai salah satu sebab adanya hubungan yang rendah antara IP MKU dengan Penampilan Kerja mereka.

Faktor-faktor lain yang mempengaruhi penampilan kerja adalah Faktor individu meliputi : Latar belakang pendidikan, masa kerja, dorongan, sikap, kemampuan dan ketrampilan,persepsi, umur, jenis kelamin, keragaman ras, pembelajaran, dan kepribadian individu. Sedangkan Faktor lingkunan meliputi : fungsi kepemimpinan, kejelasan tentang desain pekerjaan, kebijakan dan aturan, penghargaan atau imbalan, sarana prasarana, sanksi dan tingkat stress (Gibson,1996).

Hubungan yang signifikan juga didapatkan antara IP MKDK dengan Penampilan Kerja Perawat. Dengan kata lain semakin tinggi IP MKDK maka semakin tinggi pula Penampilan Kerja Perawat. Pada uji regresi linear juga ditemukan koefisien lemahnya hubungan antara Indeks Prestasi MKDK dengan Penampilan Kerja Perawat. Sedangkan koefisien diterminasi ( $R$ Square) didapatkan Indeks Prestasi MKDK berpengaruh terhadap Penampilan Kerja Perawat, namun faktor lain lebih berpengaruh. Hasil observasi pada Indeks Prestasi Mata Kuliah Dasar Keperawatan, nilai tertinggi pada mata kuliah riset keperawatan dan nilai terendah pada mata kuliah konsep dasar keperawatan. Sedangkan hasil kuisioner penampilan kerja pada ketrampilan askep, perilaku bekerja, cara berpikir, dan perilaku sosial , masingmasing berada pada tingkat sedang dari skor maksimal.

Terdapat hubungan yang signifikan antara IP Mata Kuliah Keahlian dengan Penampilan Kerja Perawat. Dengan kata lain semakin tinggi IP mata Kuliah Keahlian maka semakin tinggi pula Penampilan Kerja Perawat. Sedangkan koefisien diterminasi ( $R$ Square) didapatkan Indeks Prestasi MKK berpengaruh terhadap Penampilan Kerja Perawat, namun faktor lain lebih berpengaruh. Hasil observasi pada Indeks Prestasi Mata Kuliah Keahlian, nilai tertinggi pada praktik klinik keperawatan keluarga dan nilai terendah pada mata kuliah keperawatan jiwa. Sedangkan hasil kuisioner penampilan kerja pada ketrampilan askep, perilaku bekerja, cara berpikir, dan perilaku sosial , masingmasing berada pada tingkat sedang dari skor maksimal. IP MKK merupakan prestasi lulusan pada kelompok Mata Kuliah Keahlian pada tingkat sedang tersebut memungkinkan responden mempunyai bekal yang cukup dalam melaksanakan berbagai tindakan keperawatan.

Terdapat hubungan yang signifikan antara IP Komulatif dengan Penampilan Kerja Perawat. Dengan kata lain semakin tinggi IP Komulatif maka semakin tinggi pula Penampilan Kerja Perawat. Pada uji regresi berganda juga menunjukan bahwa lemahnya hubungan antara Indeks Prestasi Komulatif dengan Penampilan Kerja Perawat, sedangakan faktor lain lebih berpengaruh. Persamaan Regresi yang didapat yaitu $\mathrm{Y}=0,875-0,698 \mathrm{X} 1+0,339 \mathrm{X} 2+0,390 \mathrm{X} 3+$ 0,692 X4. Hal ini berarti Konstatnta sebesar 0,875 menyatakan jika tidak ada IP K, IP MKU, IP MKDK dan IP MKK, maka penampilan kerja responden adalah $0,875 \%$ atau rendah. Setiap IPK berkurang 1 $\%$ maka penampilan kerja akan menurun 0,698\%. Setiap IP MKU bertambah $1 \%$ maka penampilan kerja akan bertambah 0,339\%. Setiap IP MKDK bertambah $1 \%$ maka penampilan kerja akan bertambah 0,390\%. Setiap IP MKK bertambah $1 \%$ maka penampilan kerja akan bertambah 0,692\%. Hasil Observasi Indeks Prestasi Komulatif yang terdiri dari IP MKU, IP MKDK dan IP MKK masingmasing mayoritas, dan sebagian besar berada pada tingkat sedang.

IP Komulatif menggambarkan prestasi lulusan pada Kelompok Mata Kuliah Umum, Dasar Keahlian, dan Keahlian yang semuanya dibutuhkan sebagai bekal aplikasi kerja mereka.Dari hasil penelitian didapatkan bahwa IP Komulatif lulusan Akper Pamenang berada pada tingkatan sedang. Dari masing-masing indeks prestasi , IP Mata Kuliah Keahlian yang paling berhubungan dengan penampilan kerja perawat. Hal ini dimungkinkan karena banyaknya mata kuliah yang terdapat pada kelompok itu dan semua sangat berkaitan erat dengan profesi perawat serta banyaknya praktikum, praktik kerja lapangan di rumah sakit - rumah sakit. Dari Hasil observasi juga didapatkan tingkat yang sama antara indeks prestasi pada MKK dengan Penampilan Kerja yaitu pada tingkat sedang. 


\section{KESIMPULAN}

Indeks Prestasi Komulatif berpengaruh terhadap Penampilan kerja perawat pada semua Indeks Prestasi Mata Kuliah Umum, Mata Kuliah Dasar Keahlian dan Mata Kuliah Keahlian. Karena Indeks Prestasi Komulatif menunjukkan tingkat keberhasilan peserta didik dalam memahami seluruh materi selama menempuh pendidikan. Sedangakan materi tersebut merupakan landasan bagi peserta didik untuk melaksanakan pekerjaan yang kelak menjadi tugasnya. Kelompok Mata Kuliah Umum mengandung materi umum yang memberikan landasan untuk melanjutkan materi lainnya, danjuga hubungan sosial banyak di kelompok ini, Kelompok Mata Kuliah Dasar Keahlian mengandung materi kuliah yang mendukung perkembangan IPTEK DokKep. Sehingga semakin tinggi Indeks Prestasi pada kelompok ini maka semakin tinggi pula penguasaan IPTEK DokKep. Kemudian pada kelompok Mata Kuliah Keahlian berisikan materi kuliah yang kebanyakan berkaitan erat dengan pengalaman klinik. Sehingga sangat bermanfaat untuk melaksanakan tindakan dalam asuhan keperawatan.

\section{SARAN}

Berdasarkan kesimpulan yang telah diuraian diatas, maka saran yang dapat diberikan sebagai berikut :

1). Perlu peningkatan Sumber Daya Manusia baik Kualitas maupun kuantitas tenaga pendidik dengan menambah jumlah Dosen dan meningkatkan jenjang pendidikannya, serta melengkapi sarana dan prasarana belajar.

2). Perlunya dilakukan sistem seleksi secra jujur dan ketat untuk memperoleh calon mahasiswa yang berkualitas.

3). Perlunya peningkatan kualitas pembelajarn Asuhan Keperawatan dengan mengintensifkan mata kuliah Konsep Dasar Keperawatan dan bimbingan Asuhan Keperawatan Klinik terutama pada kegiatan evaluasi keperawatan.

4). Perlunya peningkatan Prestasi mahasiswa Akper Pamenang pada mata kuliah ilmu alam dasar (fisika \& biologi), konsep dasar keperawatan dan keperawatan jiwa dengan peningkatan bimbingan dan kesempatan praktek klinik di laboratorium dan Rumah Sakit, meningkatkan motivasi belajar mahasiswa dan penyediaan lingkungan belajar yang kondusif.
5). Perlunya memperhatikan faktor lain diluar Indeks prestasi untuk memperoleh penampilan kerja perawat yang tinggi yaitu : mengoptimalkan fungsi kepemimpinan, kejelasan pembagian tugas kerja, kebijakan dan aturan untuk peningkatan kinerja, penghargaan dan imbalan terhadap prestasi kerja, penyediaan sarana dan prasarana kerja dan sanksi atas pelanggaran kerja serta meurunkan stress kerja perawat dengan menyesuaikan beban kerja dengan kemampuan kerja.

\section{KEPUSTAKAAN}

Akper Pamenang Pare (2007). Laporan Pendidikan Akper Pamenang Pare, Pare : Sub Bagian Administrasi Akademi dan Kemahasiswaan.

Azis H. (2002). Pengantar Pendidikan Keperawatan, Jakarta : Sagung Seto.

Depkes RI (2003). Surat Keputusan Ijin Penyelenggaraan Pendidikan DIII Keperawatan Akper Pamenang Pare, Jakarta : Pusdiknakes.

Depkes RI (1997). Standard Asuhan Keperawatan, Jakarta : Sagung Seto

Gibson et. Al. (1996) Organization behavior structure processs bussines, publication inc. USA Pp : 1419.

Gillkies. D.A (1996), Nursing Management A System Approach, The W.B. Saudnders Company. Pp : 56-58.

Husin, M. (1999). Upaya Membina Sikap dan Kemampuan Profesional Perawat. Yayasan Univ. Pelita Harapan SILOAM Gleneagles Hospital. Jakarta

Husain ( 1999 ), Profesi Keperawatan menyongsong masa depan, disampaikan dalam seminar profesi keperawatan memasuki milenium III

Mangkunegara, A.A. (2000). Manajemen Sumber Daya Manusia Perusahaan, Bandung : Remaja Rosdakarya.

Nursalam (2002). Manajemen Keperawatan.Aplikasi dalam Praktik Keperawatan Profesional, Jakarta : Salemba Medika.

Nursalam (2003). Konsep dan Penerapan Metodologi Penelitian Ilmu Keperawatan. Pedoman Skripsi, Tesis dan Instrumen Keperawatan,Jakarta : Salemba Medika.

Notoatmodjo, Soekidjo (2002). Metodologi Penelitian Kesehatan, Jakarta : Rineka Cipta. 